\title{
Membangun Sistem Informasi Apotek sebagai Media Pelayanan di Masa Pandemi Corona Virus Disease 19 (Covid-19)
}

\author{
Aprilia Manganti ${ }^{1}$, Naufal Rafianto ${ }^{2}$ \\ ${ }^{1}$ Program Studi Sistem Informasi, Universitas PGRI Madiun, Jl. Setia Budi No.85, Madiun, 63118 \\ E-mail: apriliamanganti12@gmail.com \\ ${ }^{2}$ Program Studi Sistem Informasi, Universitas PGRI Madiun, Jl. Setia Budi No.85, Madiun, 63118 \\ E-mail: naufalrafianto7@gmail.com
}

\begin{abstract}
Currently, technology is developing rapidly in various aspects that are well integrated, such as the Sendang Farma Pharmacy. The system used is still considered too complicated so that the admin is less painstaking in data entry and website usage. This results in the number of goods in the system and actual stocks that do not match so that consumers are disappointed because the drug supply is not available. The scope of the problem currently observed is how to design information systems at pharmacies that aim to facilitate data processing in information so that it is effective and efficient according to user desires. The design of this system is also useful for improving customer service during the Covid-19 pandemic so that it can increase customer satisfaction. The method used in this research is the SDLC (System Development Life Cycle) method with the waterfall model. The website of the Sendang Farma Pharmacy is designed using a programming language, MySQL as a database and PHP. The result of this system is a pharmacy information system that will get information and drug inventory at the Sendang Farma Pharmacy.
\end{abstract}

Keywords—: sistem information; pharmacy; customer satisfaction; MySQL; PHP.

\section{PENDAhUluAN}

Di era digital 4.0 hampir semua organisasi menggunakan sarana teknologi informasi untuk melaksanakan kegiatannya. Banyak perusahaan yang tersingkir akibat adanya pergeseran penggunaan sarana informasi dan teknologi karena terlambat dalam berinovasi. Sistem informasi adalah suatu sistem dalam suatu organisasi yang mempertemukan kebutuhan pengolahan transaksi harian yang mendukung fungsi operasi organisasi yang bersifat manajerial dengan kegiatan strategi dari suatu organisasi untuk dapat menyediakan kepada pihak luar tertentu dengan informasi yang diperlukan untuk pengambilan keputusan. Definisi sistem informasi menurut Abdul Kadir adalah "sistem informasi adalah kerangka kerja yang mengkoordinasikan sumber daya (manusia, komputer) untuk mengubah masukan (input) menjadi keluaran (informasi), guna mencapai sasaran-sasaran perusahaan". Peranan sistem informasi adalah membantu mengendalikan dan mengorganisasikan aktivitas aktivitas dari sub sistem - sub sistem dalam organisasi sehingga membantu organisasi tersebut dalam mencapai tujuannya (Lipursari, 2012).

Teknologi informasi terus berkembang pesat beriringan dengan munculnya teknologi canggih yang dapat memberikan solusi permasalahan pada berbagai bidang yang mempunyai tujuan meringankan manusia untuk beraktivitas dan bekerja. Contoh nyata adanya perkembangan teknologi informasi yaitu adanya sistem informasi untuk proses pengolahan data obat pada Apotek Sendang Farma. Apotek merupakan sebuah tempat untuk menjalankan pekerjaan penyaluran kesehatan kepada masyarakat dan penyaluran kefarmasian (Kemenkes RI, 1993) . (Menurut Astuti, 2013) Apotek adalah usaha pada bidang perobatan yang memerlukan sistem informasi pengolahan data untuk mendukung kinerjanya. Apotek berperan sebagai penyalur kesehatan untuk masyarakat, sehingga dalam melaksanakan pelayanan terhadap masyarakat harus dilakukan semaksimal mungkin. Sistem informasi persediaan obat dibutuhkan oleh sebuah instansi untuk tercapainnya kesuksesan kinerja apotek. Dalam mencapai tujuannya, apotek memerlukan informasi yang tepat, akurat, serta efisien sehingga dibutuhkan dalam sistem informasi untuk menunjang kebutuhan Apotek dalam pengolahan data obat sehingga tercipta efektivitas dan efisiensi kinerja pada sebuah perusahaan/ instansi itu sendiri, maupun dalam meningkatkan pelayan apotek terhadap Konsumen. Walaupun apotek Sendang Farma sudah memiliki sistem sendiri, akan tetapi sistem tersebut masih dianggap rumit sehingga admin kurang telaten dalam penginputan stok obat pada sistem. Hal buruk yang sering terjadi adalah stok persediaan yang ada pada etalase, kartu stok dan pada sistem tidak sesuai. Banyak konsumen yang kecewa karena ternyata produk obat yang dicari tidak tersedia. Maka dari itu untuk memudahkan kinerjanya, Apotek seharusnya mempunyai sebuah sistem informasi pengolahan data persediaan obat yang sudah terkomputerisasi. Sistem informasi berperan penting dalam mengelola laporan persediaan obat pada Apotek Sendang Farma. Setiap apotek akan memberikan pelayanan terbaik. Salah satu indikator yang digunakan untuk mengevaluasi kualitas pelayanan di apotek adalah dengan mengukur tingkat kepuasan pelanggan ( Kotler dan Kevin, 2007). Kepuasaan pelanggan merupakan penilaian tersendiri seseorang yang muncul setelah membandingkan hasil produk yang dipikirkan terhadap kinerja yang dihasilkan. Selain itu sistem informasi dapat mempermudah aktivitas input, penyimpanan, dan pengambilan data, sehingga sistem tersebut dapat mempermudah dalam input data, pencarian data, dan output data secara otomatis, efektif dan efisien. 


\section{METODE PENELITIAN}

\section{A. Tempat Penelitian}

Lokasi penelitian di Jl. Raya Madiun-Dimong, Ds. Sendangrejo RT.09 RW.02, Madiun Jawa Timur. Apotek Sendang Farma berada tepat di pinggir Jl. Raya Madiun-Dimong.

\section{B. Alur Penelitian}

Penelitian ini menggunakan metode perancangan yaitu metode SDLC (System Development Life Cycle) dengan model waterfall. Metode waterfall adalah metode yang menyediakan pendekatan alur hidup perangkat lunak secara sekuensial atau berurutan mulai dari analisa, desain, pengkodean, pengujian dan pendukung / support (Rosa dan Shalahuddin, 2013).

Adapun susunan dalam metode ini yaitu :

\section{Analisis}

Merupakan suatu cara untuk mengumpulkan data yang akan digunakan dalam menyelesaikan suatu permasalahan (Suryadi dan Zulaikhah, 2019). Pada website apotek Sendang Farma pengguna yaitu admin atau karyawan apotek tersebut dan konsumen (pengguna).

\section{Desain Sistem}

Merupakan tahap perancangan suatu website untuk menjadi satu kesatuan yang utuh sebelum ke tahap implementasi agar dapat berfungsi dengan baik dan sesuai dengan kebutuhan pengguna. Tahap desain sistem dapat dilakukan dengan menggunakan Unified Modeling Language (UML). UML merupakan alat bantu yang dapat dipergunakan dalam melakukan desain terhadap sistem yang akan dirancang ( Tirtadarma dkk., 2018). UML sendiri juga dapat diartikan sebagai suatu model perancangan sistem yang berkelebihan dapat mempermudah developer sistem untuk merancang sistem yang dibuat karena bersifat berorientasikan pada objek (Teguh, 2018).

\section{Implementasi}

Merupakan upaya untuk menerapkan desain sistem yang telah di buat menjadi perangkat lunak atau software yang dapat di gunakan sesuai kebutuhan pengguna.

\section{Pengujian/Testing}

Merupakan cara untuk mengetahui setiap kelemahan yang terdapat pada software yang telah di buat sebelumnya agar kualitas dapat diketahui dan di perbaiki apabila terdapat kesalahan.

Gambaran umum sistem yang dikerjakan :

1. Use Case diagram digunakan untuk menggambarkan atau menjelaskan secara ringkas siapa (aktor) yang menggunakan sistem dan apa saja yang bisa dilakukannya (aktor). Menurut (Whitten dan Bentley, 2009). Use Case diagram adalah sebuah diagram yang mendeskripsikan interaksi antara sistem dengan bagian eksternal dari sistem serta dengan pengguna. Model perancangan Use Case ini bertujuan untuk menggambarkan perilaku masing-masing aktor yang saling terhubung dengan sistem (Chairul, 2019).

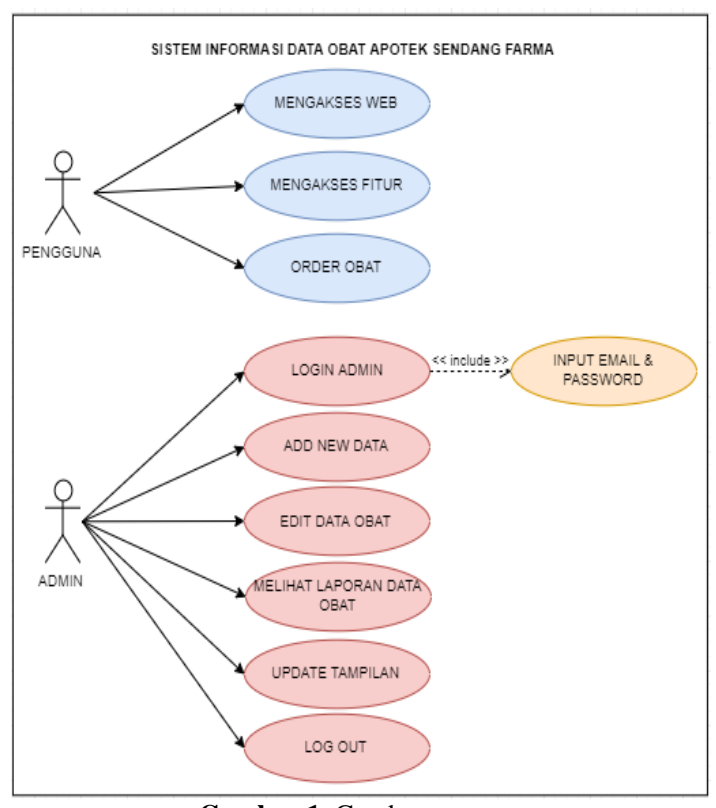

Gambar 1. Gambar use case 
2. Perancangan Sistem

Sistem Informasi Apotek Sendang Farma dibuat dengan menggunakan PHP yang merupakan bahasa yang disertakan dalam dokumen HTML sekaligus bekerja disisi server (Prabowo dkk., 2017) dan MySQL yang merupakan software yang tergolong sebagai DBMS (Database Management System) yang bersifat Open Source (Kadir 1999). Database yang dibuat dalam sistem informasi ini menggunakan MySQL. Berikut ini merupakan tampilan database keseluruhan yang telah dibuat :

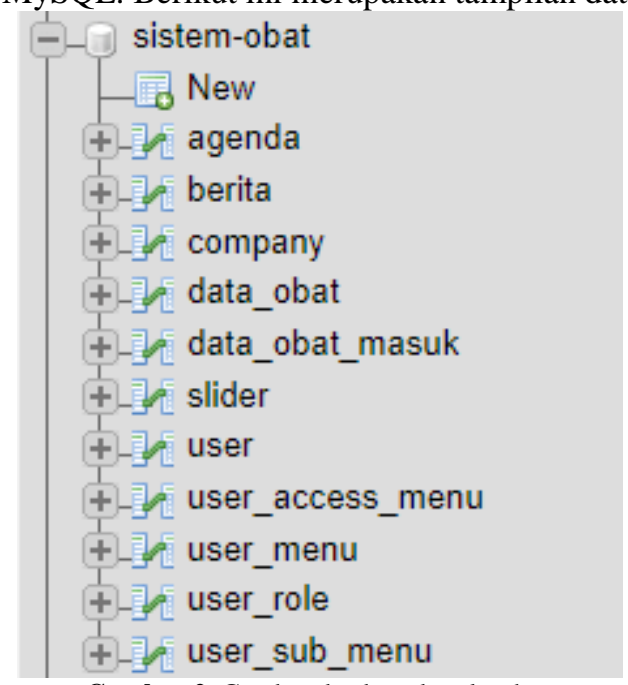

Gambar 2. Gambar database keseluruhan

\section{III.HASIL DAN PEMBAHASAN}

\section{A. Analisa Kebutuhan}

Berdasarkan hasil wawancara oleh pemilik dan karyawan Apotek Sendang Farma, sistem yang ada di anggap masih terlalu sulit sehingga karyawan disana belum mampu mengoperasikan dengan maksimal. Dengan adanya permasalahan tersebut maka penulis membuat sistem informasi Apotek berbasis website yaitu Website Profile serta data obat yang tersedia disana. Website tersebut diharapkan mampu meningkatkan pelayanan konsumen pada masa pandemi covid - 19. Selain itu website juga mempermudah konsumen untuk melihat atau mengecek data obat yang diperlukan. Setelah data obat tersebut tersedia maka konsumen dapat dengan mudah memesan obat tersebut melalui whatsapp yang sudah terintegrasi dengan website tersebut, sehingga konsumen tinggal datang dan mengambil pesanan obat tanpa harus memakan waktu yang lama.

Berikut merupakan Analisa Tabel Kebutuhannya:

\begin{tabular}{|l|l|l|l|}
\hline NO & \multicolumn{1}{|c|}{ KEBUTUHAN } & AKTOR & USE CASE \\
\hline 1. & $\begin{array}{l}\text { Pengguna dapat mengakses } \\
\text { website secara online }\end{array}$ & Pengguna & $\begin{array}{l}\text { Mengakses } \\
\text { Web }\end{array}$ \\
\hline 2. & $\begin{array}{l}\text { Pengguna dapat melihat } \\
\text { fitur fitur yang ada pada } \\
\text { website }\end{array}$ & Pengguna & Akses Fitur \\
\hline 3. & $\begin{array}{l}\text { Pengguna mencari obat } \\
\text { yang akan di beli melalui } \\
\text { fitur data obat }\end{array}$ & Pengguna & $\begin{array}{l}\text { Fitur data } \\
\text { obat }\end{array}$ \\
\hline 4. & $\begin{array}{l}\text { Pengguna memesan obat } \\
\text { melalui whatsapp pemilik } \\
\text { yang sudah disambungkan } \\
\text { dari fitur data obat }\end{array}$ & Pengguna & $\begin{array}{l}\text { Link } \\
\text { Whatsapp }\end{array}$ \\
\hline 5. & $\begin{array}{l}\text { Admin melakukan login } \\
\text { mengakses page admin }\end{array}$ & Admin & $\begin{array}{l}\text { Log in } \\
\text { admin }\end{array}$ \\
\hline 6. & $\begin{array}{l}\text { Admin menginput data } \\
\text { obat baru / masuk didalam } \\
\text { website }\end{array}$ & Admin & $\begin{array}{l}\text { Add New } \\
\text { Data }\end{array}$ \\
\hline 7. & $\begin{array}{l}\text { Admin dapat mengedit data } \\
\text { obat didalam website }\end{array}$ & Admin & Edit data \\
\hline 8. & $\begin{array}{l}\text { Admin dapat melihat } \\
\text { laporan data obat }\end{array}$ & Admin & $\begin{array}{l}\text { Laporan } \\
\text { Data obat }\end{array}$ \\
\hline 9. & $\begin{array}{l}\text { Admin update tampilan } \\
\text { pada website }\end{array}$ & Admin & $\begin{array}{l}\text { Update } \\
\text { tampilan } \\
\text { website }\end{array}$ \\
\hline 10. & $\begin{array}{l}\text { Admin logout setelah } \\
\text { memperbarui data didalam }\end{array}$ & Admin & $\begin{array}{l}\text { Log out } \\
\text { admin }\end{array}$ \\
\hline
\end{tabular}




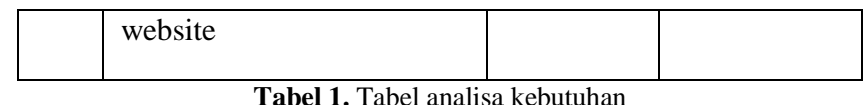

Tabel 1. Tabel analisa kebutuhan

\section{B. Perancangan Sistem}

Menurut (Yakub, 2012) perancangan sistem dapat diartikan sebagai penggambaran, perencanaan, dan pembuatan sketsa atau pengaturan dari beberapa elemen terpisah ke dalam satu kesatuan yang utuh dan berfungsi. Dalam pembuatan website Apotek Sendang Farma menggunakan rancangan antarmuka/ Interface dengan melihat kebutuhan fitur yang diperlukan serta informasi yang lengkap dari Apotek Sendang Farma tersebut. User Interface (UI) adalah tampilan antarmuka yang tampak atau berada diantara pengguna (user) dengan piranti tersebut (Litalien et al., 2009). Desain yang telah di implementasikan menghasilkan program yang dapat dan mudah di pergunakan oleh pengguna/konsumen dan admin.

\section{Halaman Front End}

Bagian front-end dari sebuah website adalah bagian yang langsung dilihat oleh user. User juga bisa langsung berinteraksi pada bagian ini.

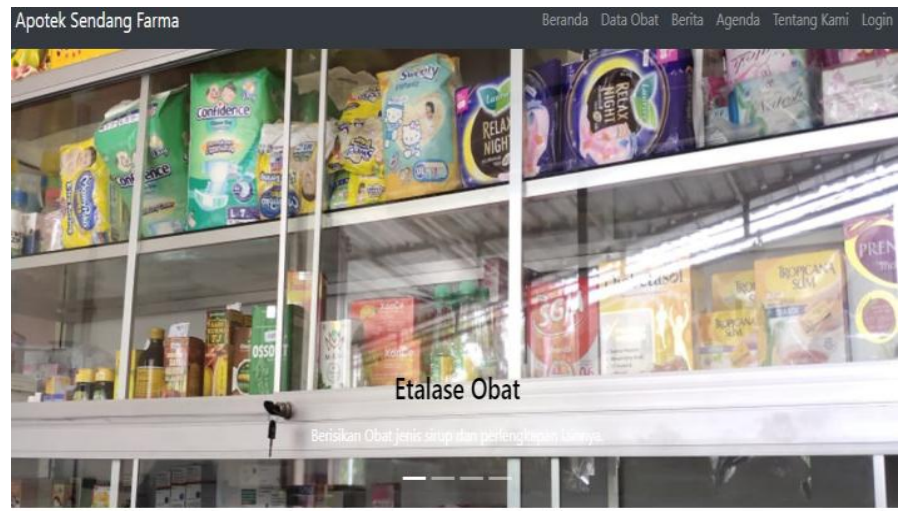

All Data Obat

Berita

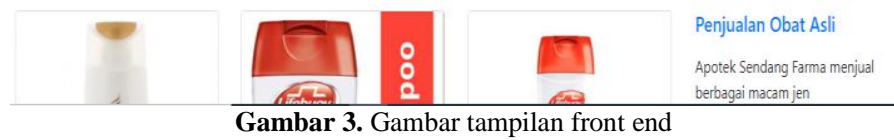

\section{Halaman Back End}

Back-end adalah bagian belakang layar dari sebuah website. Tampilan ini berguna untuk memudahkan admin menginput, update, maupun delete data yang ada pada website.

a. Form Login

Login panel digunakan untuk admin masuk dan dapat mengakses halaman admin / halaman back end.

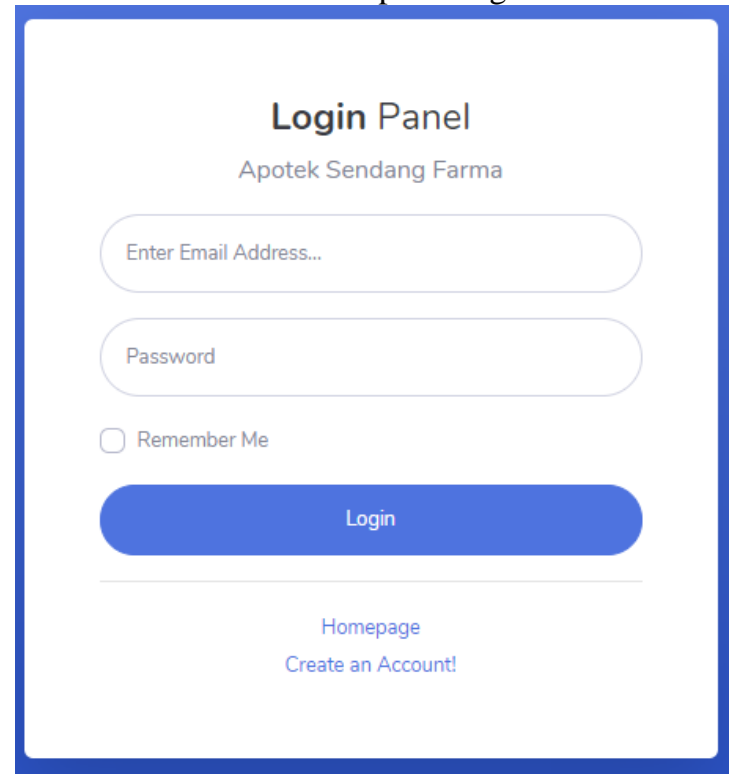

Gambar 4. Gambar login panel 
b. Halaman admin Halaman admin digunakan untuk menginput, mengedit dan menghapus data agar memudahkan kerja admin.

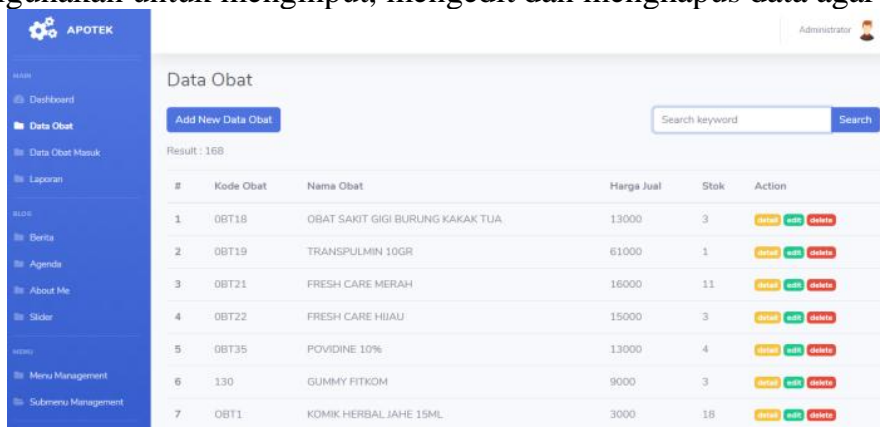

Gambar 5. Gambar tampilan admin

\section{Pengujian Sistem}

Hasil dari sistem informasi apotek yang telah dibuat selanjutnya dilakukan tahap testing/pengujian untuk membuktikan apakah sudah berhasil atau masih ada kendala pada proses pengujian. Sebelum program diterapkan maka program harus bebas terlebih dahulu darikesalahan. Pengujian sistem dilakukan dengan menggunakan teknik pengujian white box dan blacx box testing.

a. White Box Testing

White box testing merupakan pengujian yang didasarkan pada pengecekan terhadap detail perancangan atau code program untuk menemukan error atau kesalahan sehingga program dapat dibenarkan dengan sempurna.

Adapun alur white box testing pada project website apotek adalah sebagai berikut : Melihat kode program dan mencari kesalahan/ errornya ada dibagian mana biasanya kita melihat langsung pada halaman website yang dapat dilihat pada local host, ketika terdapat error baru dibenarkan pada bagian mana yang salah sampai hasilnya sesuai rancangan.

b. Black Box Testing

Pada Black Box Testing dilakukan pengujian yang didasarkan pada detail aplikasi seperti tampilan aplikasi, fungsi-fungsi yang ada pada aplikasi, dan kesesuaian alur fungsi dengan bisnis proses yang diinginkan oleh customer. Black-box Testing ini lebih menguji ke Tampilan Luar(Interface) dari suatu aplikasi agar mudah digunakan oleh Customer (Jaya, 2018). Pengujian ini tidak melihat dan menguji souce code program. Black-box Testing bekerja dengan mengabaikan struktur control sehingga perhatianya hanya terfokus pada informasi domain.

- Halaman Front End

\begin{tabular}{|c|l|l|l|}
\hline No & \multicolumn{1}{|c|}{$\begin{array}{c}\text { Skenario } \\
\text { pengujian }\end{array}$} & \multicolumn{1}{|c|}{$\begin{array}{c}\text { Hasil yang di } \\
\text { harapkan }\end{array}$} & Kesimpulan \\
\hline 1 & Klik fitur beranda & $\begin{array}{l}\text { Sistem akan } \\
\text { memunculkan } \\
\text { halaman pada fitur } \\
\text { beranda }\end{array}$ & Valid \\
\hline 2 & $\begin{array}{l}\text { Klik fitur data } \\
\text { obat }\end{array}$ & $\begin{array}{l}\text { Sistem akan } \\
\text { memunculkan } \\
\text { halaman pada fitur } \\
\text { data obat }\end{array}$ & Valid \\
\hline 3 & $\begin{array}{l}\text { Mengisi data obat } \\
\text { yang dicari } \\
\text { langsung klik } \\
\text { tombol "search" }\end{array}$ & $\begin{array}{l}\text { Sistem akan } \\
\text { menampilkan data } \\
\text { obat yang dicari }\end{array}$ & Valid \\
\hline 4 & $\begin{array}{l}\text { Klik "detail" pada } \\
\text { produk data obat }\end{array}$ & $\begin{array}{l}\text { Sistem akan } \\
\text { memunculkan detai } \\
\text { data obat }\end{array}$ & Valid \\
\hline 5 & $\begin{array}{l}\text { Klik "Whatsapp" } \\
\text { apabila konsumen } \\
\text { ingin memesan } \\
\text { produk }\end{array}$ & $\begin{array}{l}\text { Sistem otomatis } \\
\text { mengubungkan } \\
\text { dengan nomor } \\
\text { whatsapp pemilik } \\
\text { apotek }\end{array}$ & Valid \\
\hline 6 & Klik fitur berita & $\begin{array}{l}\text { Sistem akan } \\
\text { memunculkan } \\
\text { halaman pada fitur } \\
\text { berita }\end{array}$ & Valid \\
\hline
\end{tabular}


PILAR TEKNOLOGI : Jurnal IImiah IImu-IImu Teknik

Website : http://pilar.unmermadiun.ac.id/index.php/pilarteknologi

\begin{tabular}{|c|l|l|l|}
\hline 7 & Klik fitur agenda & $\begin{array}{l}\text { Sistem akan } \\
\text { memunculkan } \\
\text { halaman pada fitur } \\
\text { agenda }\end{array}$ & Valid \\
\hline 8 & $\begin{array}{l}\text { Klik fitur tentang } \\
\text { kami }\end{array}$ & $\begin{array}{l}\text { Sistem akan } \\
\text { memunculkan } \\
\text { halaman informasi } \\
\text { mengenai Apotek }\end{array}$ & Valid \\
\hline 9 & Klik fitur login & $\begin{array}{l}\text { Sistem akan } \\
\text { memunculkan panel } \\
\text { login admin }\end{array}$ & Valid \\
\hline
\end{tabular}

Tabel 2. Tabel black box testing front end

- Halaman Back End

\begin{tabular}{|c|c|c|c|}
\hline No & $\begin{array}{c}\text { Skenario } \\
\text { pengujian }\end{array}$ & $\begin{array}{c}\text { Hasil yang di } \\
\text { harapkan }\end{array}$ & Kesimpulan \\
\hline 1 & $\begin{array}{l}\text { Mengosongkan } \\
\text { email dan } \\
\text { password, } \\
\text { langsung klik } \\
\text { tombol "masuk" }\end{array}$ & $\begin{array}{l}\text { Sistem akan } \\
\text { menolak akses login } \\
\text { dan memunculkan } \\
\text { peringatan The } \\
\text { Email field is } \\
\text { required dan The } \\
\text { Password field is } \\
\text { required. }\end{array}$ & Valid \\
\hline 2 & $\begin{array}{l}\text { Mengisi email } \\
\text { dan } \\
\text { mengosongkan } \\
\text { password, } \\
\text { langsung klik } \\
\text { tombol "masuk" }\end{array}$ & $\begin{array}{l}\text { Sistem akan } \\
\text { menolak akses login } \\
\text { dan memunculkan } \\
\text { peringatan "The } \\
\text { Password field is } \\
\text { required" pada form } \\
\text { password }\end{array}$ & Valid \\
\hline 3 & $\begin{array}{l}\text { Mengisi email } \\
\text { dan password, } \\
\text { langsung klik } \\
\text { tombol "masuk" }\end{array}$ & $\begin{array}{l}\text { Sistem akan } \\
\text { menerima akses } \\
\text { login dan langsung } \\
\text { menampilkan } \\
\text { halaman back end } \\
\text { admin }\end{array}$ & Valid \\
\hline 4 & $\begin{array}{l}\text { Mengisi email } \\
\text { dan password, } \\
\text { namun password } \\
\text { yang dimasukkan } \\
\text { password yang } \\
\text { salah, langsung } \\
\text { klik tombol } \\
\text { "masuk" }\end{array}$ & $\begin{array}{l}\text { Sistem akan } \\
\text { menolak akses login } \\
\text { dan memunculkan } \\
\text { peringatan "Wrong } \\
\text { password" }\end{array}$ & Valid \\
\hline 5 & $\begin{array}{l}\text { Klik Tombol } \\
\text { "Add New" }\end{array}$ & $\begin{array}{l}\text { Sistem akan } \\
\text { menampilkan form } \\
\text { yang harus diisi }\end{array}$ & Valid \\
\hline 6 & $\begin{array}{l}\text { Mengosongkan } \\
\text { data dan langsung } \\
\text { klik tombol } \\
\text { "Insert Data" }\end{array}$ & $\begin{array}{l}\text { Sistem akan } \\
\text { menolak akses add } \\
\text { data dan } \\
\text { memunculkan } \\
\text { peringatan "The } \\
\text { field is required" }\end{array}$ & Valid \\
\hline 7 & $\begin{array}{l}\text { Klik Tombol } \\
\text { "Detail" }\end{array}$ & $\begin{array}{l}\text { Sistem akan } \\
\text { memunculkan detail } \\
\text { dari data }\end{array}$ & Valid \\
\hline 8 & $\begin{array}{l}\text { Klik Tombol } \\
\text { "Edit" }\end{array}$ & $\begin{array}{l}\text { Sistem akan } \\
\text { memunculkan semua } \\
\text { data yang akan di } \\
\text { edit }\end{array}$ & Valid \\
\hline 9 & $\begin{array}{l}\text { Klik Tombol } \\
\text { "Delete" }\end{array}$ & $\begin{array}{l}\text { Sistem akan } \\
\text { menghapus data } \\
\text { yang didelete }\end{array}$ & Valid \\
\hline
\end{tabular}




\begin{tabular}{|c|l|l|l|}
\hline 10 & $\begin{array}{l}\text { Klik Tombol } \\
\text { "Print" pada } \\
\text { menu laporan }\end{array}$ & $\begin{array}{l}\text { Sistem akan } \\
\text { menampilkan } \\
\text { laporan berdasarkan } \\
\text { tanggal, bulan dan } \\
\text { tahun sesuai dengan } \\
\text { keinginan admin }\end{array}$ & Valid \\
\hline 11 & $\begin{array}{l}\text { Klik tombol } \\
\text { "change } \\
\text { password" pada } \\
\text { submenu change } \\
\text { password }\end{array}$ & $\begin{array}{l}\text { Sistem akan } \\
\text { menampilkan } \\
\text { peringatan } \\
\text { "Password } \\
\text { changed!" }\end{array}$ & Valid \\
\hline 12 & $\begin{array}{l}\text { Klik tombol } \\
\text { "access" pada } \\
\text { submenu access } \\
\text { menu user }\end{array}$ & $\begin{array}{l}\text { Sistem akan } \\
\text { menampilkan menu } \\
\text { apa saja yang dapat } \\
\text { diakses dengan tanda } \\
\text { centang didalam } \\
\text { kotak }\end{array}$ & Valid \\
\hline
\end{tabular}

Tabel 3. Tabel black box testing back end

\section{IV.KESIMPULAN}

Berdasarkan penelitian yang telah dilakukan dalam analisa dan perancangan sistem informasi website Apotek Sendang Farma guna mempermudah kinerja karyawan dengan menggunakan metode waterfall yang melalui beberapa tahap diantaranya analisis, desain sistem, implementasi dan pengujian. Website profil dan data obat bertujuan untuk meningkatkan pelayanan pada masa pandemi covid-19. Tampilan website ini terdapat dua tampilan yaitu tampilan pengguna/konsumen dan tampilan untuk admin yang memudahkan admin menginput, update maupun menhapus data yang ada pada website. Dari hasil pengujian yang telah dilakukan didapatkan hasil bahwa fitur-fitur di dalam website tersebut tepat guna, mudah digunakan serta sesuai dengan kebutuhan.

\section{UCAPAN TERIMAKASIH}

Ucapan terimakasih penulis kepada Bapak Ridho Pamungkas selaku dosen pembimbing yang telah meluangkan waktunya untuk membimbing dan berbagi ilmu dan masukan yang diberikan. Terimakasih untuk orang tua yang senantiasa mendukung serta teman - teman yang sudah memberikan semangat selama ini, untuk menyelesaikan jurnal ini. Tak lupa penulis ucapkan syukur alhamdulillah atas karunia Allah SWT yang telah memberikan karunia-Nya sehingga penulis dapat menyelesaikan penelitian ini.

\section{VI.DAFTAR PUSTAKA}

Kemenkes RI Tentang Perubahan Atas Peraturan Menteri Kesehatan RI No. 922 Tahun 1993 Tentang Ketentuan dan Tata Cara Pemberian Izin Apotek Astuti, Puspita Dwi. Perancangan Sistem Informasi Penjualan Obat Pada Apotek Jati Farma Arjosari. 2013. ISSN: 2302-1136. Universitas Surakarta: Fakultas Teknologi Informatika. Vol 2, No.1 Maret 2013.

Kotler, Philip dan Kevin Lane Keller., 2007. Manajemen Pemasaran, Edisi Kedua Belas, Jilid 1, dialih bahasakan oleh Benjamin Molan, Jakarta: PT Indeks.

Rosa A.S \& M.Shalahuddin., 2013, Rekayasa Perangkat Lunak Terstruktur dan Berorientasi Objek. Bandung : Informatika Bandung.

Suryadi and Y. S. Zulaikhah, "Rancang Bangun Sistem Pengelolaan Arsip Surat Berbasis Web Menggunakan Metode Waterfall," J. Khatulistiwa Inform., vol. 7, no. 1, pp. 13-21, 2019.

E. Tirtadarma, A. E. B. Waspada, and E. F. Jasjfi, "Kajian Peranan Desain UX (Pengalaman Pengguna) - UI (Antar Muka Pengguna) Mobile Application Kategori Transportasi Online terhadap Gaya Hidup Bertransportasi Masyarakat Urban,” J. Seni dan Reka Ranc. J. Ilm. Magister Desain, vol. 1, no. 1, p. 181207,2018

M Teguh Prihandoyo, "Unified Modeling Language (UML) Model Untuk Pengembangan Sistem Informasi Akademik Berbasis Web,” J. Inform. J. Pengemb. IT, vol. 3, no. 1, pp. 126-129, 2018.

Bentley, Whitten. (2009). Systems Analysis and Design Methods Editions. MA:McGraw-hill Irwin. Boston.

Chairul Anwar, "Analisa dan Perancangan Sistem Informasi Human Resources Development Pada PT. Semacom Integrated dengan Menggunakan Metode Waterfall,” Int. J. Educ. Sci. Technol. Eng., vol. 2, no. 1, pp. 19-38, 2019.

Prabowo, Faizal, \& Syani, M. "Sistem Informasi Pengolahan Sertifikat Berbasis Web Di Divisi Training Seamolec”. Jurnal Masyarakat Informatika Indonesia, 2(1), 73- 81. 2017.

Kadir, Abdul. 1999. Konsep dan Tuntutan Praktis Basis Data. Yogyakarta. Andi.

Yakub. 2012. Pengantar Sistem Informasi. Yogyakarta:GRAHA ILMU 2009.

D. Litalien et al., "No Title تزازب الاب إl," Bifurcations, vol. 45, no. 1, pp. 1-19, 2009.

Jaya, T. S. (2018). Pengujian Aplikasi dengan Metode Blackbox Testing Boundary Value Analysis (Studi Kasus: Kantor Digital Politeknik Negeri Lampung). Jurnal Informatika: Jurnal Pengembangan IT, 3(1), 45-48. 